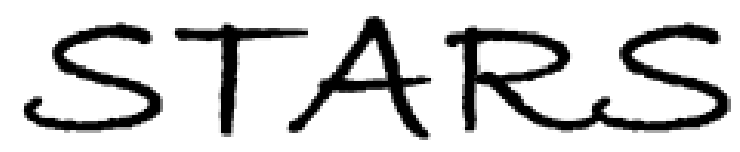

University of Central Florida

STARS

Faculty Scholarship and Creative Works

2-9-2022

\title{
Educational Leadership Preparation and Professional Roles: Are We Serving the Needs of Leadership Roles Along the Leadership Continuum?
}

Daniel W. Eadens

University of Central Florida, daniel.eadens@ucf.edu

Marjorie Ceballos

University of Central Florida, marjorie.ceballos@ucf.edu

Part of the Educational Leadership Commons

Find similar works at: https://stars.library.ucf.edu/ucfscholar

University of Central Florida Libraries http://library.ucf.edu

This Paper is brought to you for free and open access by STARS. It has been accepted for inclusion in Faculty Scholarship and Creative Works by an authorized administrator of STARS. For more information, please contact STARS@ucf.edu.

\section{Original Citation}

Eadens, Daniel W., and Marjorie Ceballos. "Educational Leadership Preparation and Professional Roles: Are We Serving the Needs of Leadership Roles Along the Leadership Continuum?" Journal of Research on Leadership Education, Feb. 2022, doi:10.1177/19427751221076416.

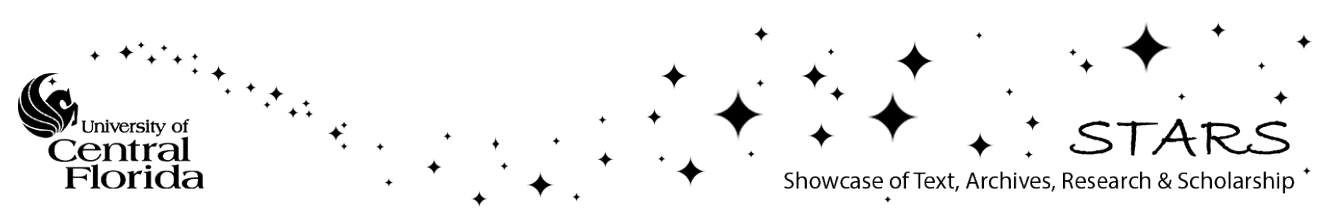




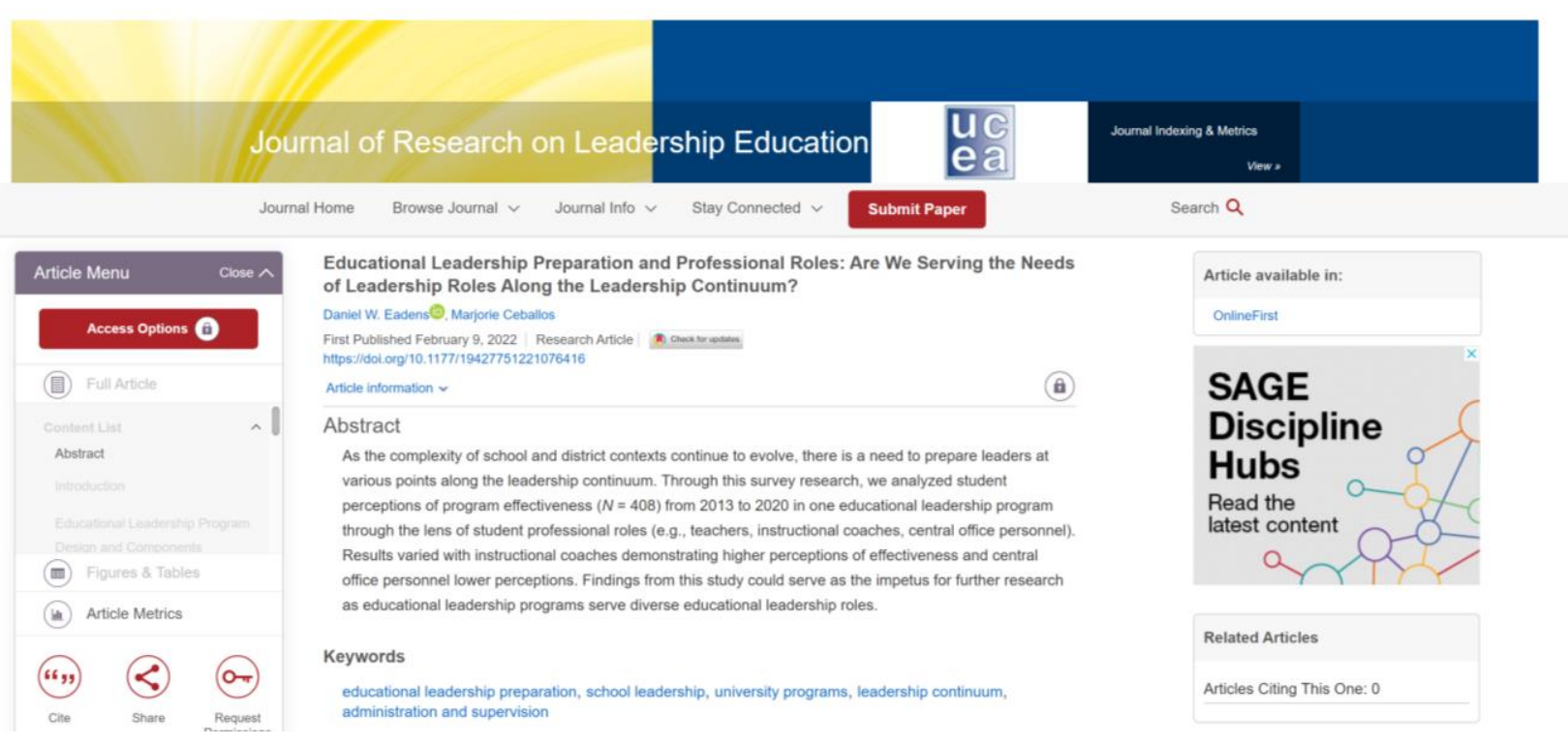

\title{
Educational Leadership Preparation and Professional Roles: Are We Serving the Needs of Leadership Roles Along the Leadership Continuum?
}

Journal of Research on Leadership Education $\mathrm{I}-24$

(C) The University Council for Educational Administration 2022 Article reuse guidelines: sagepub.com/journals-permissions DOI: I0.II77/|942775|22I0764|6 journals.sagepub.com/home/jrl @SAGE

\section{Daniel W. Eadens' ${ }^{(D)}$ and Marjorie Ceballos'}

\author{
Preprint below:
}




\title{
Educational Leadership Preparation and Professional Roles: Are We Serving the Needs of Leadership Roles Along the Leadership Continuum?
}

\begin{abstract}
As the complexity of school and district contexts continue to evolve, there is a need to prepare leaders at various points along the leadership continuum. Through this survey research, we analyzed student perceptions of program effectiveness $(N=408)$ from 2013 to 2020 in one educational leadership program through the lens of student professional roles (e.g., teachers, instructional coaches, central office personnel). Results varied with instructional coaches demonstrating higher perceptions of effectiveness and central office personnel lower perceptions. Findings from this study could serve as the impetus for further research as educational leadership programs serve diverse educational leadership roles.
\end{abstract}

Keywords: educational leadership preparation, school leadership, university programs, leadership continuum, administration and supervision 


\section{Introduction}

Improving educational outcomes for students was the impetus for crafting of federal legislation since the publication of A Nation at Risk in 1983. Since this landmark report, the No Child Left Behind (NCLB) Act Of 2001, Race to the Top Fund (RTT) of 2012, and, most recently, the Every Student Succeeds Act (ESSA) of 2015 attempted to address student outcomes by prompting states to engage in comprehensive educational reform. In response to various factors, including federal and state educational demands, the adoption of new national professional standards for principals, and research on principals' impact on student outcomes, various states have engaged in school leadership improvement efforts (Riley \& Meredith, 2017).

Educational leadership preparation programs occupy a critical space in overall school leader improvement efforts because programs are tasked with preparing future cadres of leaders to produce positive outcomes. Hattie (2009) found that after teachers, school leaders were the most important factor impacting student achievement. School leaders should be steeped in instructional leadership, school culture leadership, and change leadership to lead successful school improvement efforts and/or reforms (Dolph, 2017). Through instructional leadership practices, school leaders contribute to enhanced student outcomes by supporting and advancing instruction (Dolph, 2017; Nettles \& Herrington, 2007). To establish a trusting school culture that leads to school improvement, skilled school leaders participate in professional learning with teachers, seek to understand teachers' strengths leveraging them, and possess effective communication skills (Hollingworth et al., 2018). Finally, to be effective change agents for school improvement, successful school leaders practice distributed leadership to build "ownership and consensus" as improvements are planned for and implemented (Dolph, 2017, p. 382). Given the range of skills and competencies needed of school leaders, researchers examined 
school leadership preparation, investigating program structure, program effectiveness, satisfaction, and impact (Anderson, 2018; Bogler \& Nir, 2015; Cosner, 2019; Grissom et al., 2019; Ingle et al., 2018; Mullen \& Eadens, 2018; Ni, Hollingworth et al., 2017; Ni et al., 2019; Orphanos \& Orr, 2014; Orr, 2011; Orr et al., 2018; Orr \& Orphanos, 2011; Perrone \& Tucker, 2019). Through analyses of these factors, researchers underscored program components in need of enhancement to improve the quality of educational leadership programs to better prepare future school leaders.

In light of these findings and with a focus on improving educational leadership program quality, we sought to build on previous research through the examination of overall student perceptions and by investigating student perceptions of program effectiveness based on students' professional roles in one educational leadership program. As we know, school leaders exist along a leadership continuum, ranging from roles in quasi-leadership (i.e., teacher leaders, academic deans, instructional coaches, etc.) to individuals in traditional leadership roles (i.e., school principals, assistant principals, central office [school district] leaders, etc.). These roles operate along the school leadership continuum because individuals operating in leadership capacities "provide direction and exert influence in order to achieve the school's goals" (Leithwood \& Riehl, 2003, p. 2). School goals encompassing educational reform efforts (i.e., instructional improvements) to advance student learning hinge upon the leadership skills of those in traditional leadership roles and leadership from teachers and instructional coaches. Robinson et al. (2008), for example, found that principal competencies related to instructional leadership contributed to student learning. Further, Hopkins et al. (2013) found that teacher leaders were instrumental in instructional improvements at their school sites and across school sites. Similarly, Woulfin (2018) found that instructional coaches were a key component of a school district's 
drive to attain instructional improvements in response to state accountability requirements. Since the leadership continuum is leveraged to advance educational reforms, it is necessary to understand how an educational leadership program contributes to overall leadership development. Therefore, the purpose of this study was to engage in a continuous improvement effort to determine if we were serving the different professional roles (e.g., teachers, instructional coaches, and school district leaders) represented in our program based on students' perceptions.

While this research study was completed using student perception data from one educational leadership program in Florida, we believe it is relevant to the overall discussion on quality educational leadership programs, particularly due to emphasis on distributed leadership (Elmore, 2000; Harris \& Spillane, 2008; Spillane, 2005) and preparing leaders along the leadership continuum (New Leaders, 2018). As the complexity of school and school district contexts continue to evolve, there is a need to prepare leaders at various points along the continuum. Educational leadership programs are well positioned to contribute to overall leadership preparation to advance school outcomes. Our review of the literature includes a discussion on educational leadership program design and components, research on teacher, instructional coach, and central office leadership to set the context for the professional roles that may be represented in educational leadership programs; and present information on educational leadership program that served as the data source for this study.

\section{Educational Leadership Program Design and Components}

Since the early 2000s, the literature on educational leadership preparation has focused on analyzing effectiveness, satisfaction, and impact of educational leadership programs to determine program quality. The focus on program effectiveness arose based on the perceived ineffectiveness of university-based educational leadership programs to prepare future leaders 
adequately to meet the demands of outcomes-based educational reforms (Elmore, 2000; Hess \& Kelly, 2005). Principal surveys indicated that participants found that the educational leadership curriculum did not prepare them for the principalship (Levine, 2005), which suggested a need for change to the design of educational leadership programs (Lashway, 2003). Further exploring the issue of program design leading to effective educational leadership preparation, Levine (2005) proposed nine components on which to assess the quality of educational leadership programs which included the purpose, curricular coherence, curriculum balance, faculty composition, admissions, degrees, research, finances, and assessment of programs (p. 13).

While the discussion over program effectiveness took place, other scholars sought to understand the scope and depth of the research on educational leadership preparation. Murphy and Vriesenga (2006) in review of school leadership preparation research found that more investigations were needed to make evidence-based improvements to educational leadership preparation. Specifically, the researchers noted the need for studies that examined the current state of educational leadership preparation, the impact of reform efforts on programs, effective educational leadership programs, alternative pathways to educational leadership preparation, educational leadership program outcomes, and the environment in which educational leadership programs operated (e.g., state policy, influence of foundations, etc.; Murphy \& Vriesenga, 2006). The field responded to educational leadership research need with various scholars examining exemplary educational leadership programs as defined by the University Council for Educational Administration (UCEA) or programs aligned to UCEA to identify components, processes, and learning experiences contributing to quality educational leadership preparation (Anderson et al., 2018; Campanotta et al., 2018; Cosner, 2019; Cunningham \& Lochmiller, 2019; Cunningham et al., 2019; VanGronigen et al., 2018). Components of quality educational leadership programs 
included curricula aligned to national standards, partnering with school districts, and clinical experiences through field-based internships (Anderson et al., 2018; Campanotta et al., 2018). Further, the literature identified "powerful learning experiences" (PLEs) as critical to leadership preparation because they support development of future leaders' approaches to decision-making in various contexts (Cunningham et al., 2019, p. 75) and to the development of interpersonal and intrapersonal skills necessary in leadership (VanGronigen et al., 2018). Using Young's (2015) nine PLE characteristics, Cunningham and colleagues (2019) described PLEs as learning activities which allowed future leaders to engage in "authentic," "problem-finding" activities that required them to engage in "sensemaking around critical problems of practice" (p. 81). Further, the authors posited that PLEs should involve an equity perspective, allow for collaboration, involve faculty and students as co-learners, and allow for reflection on the PLE. One such example of a learning activity aligned to the PLE description is the use of mixed reality simulations to practice communicating with teachers and parents (Ceballos et al., in press). Findings from research on the use of mixed reality simulations found that students perceived themselves to have increased confidence in communicating with parents and teachers (Ceballos et al., 2020).

\section{Continuous Improvement and Impact of Educational Leadership Programs}

In response to the criticisms levied in the early 2000s, educational leadership programs engaged in program redesigns using the Interstate School Leaders Licensure Consortium (ISLLC) standards (Hess \& Kelly, 2005; McCarthy, 2015). However, although program redesigns were completed, oftentimes redesigns consisted of program modifications rather than wholesale changes to programs (McCarthy, 2015). Although complete redesigns were not commonplace, program modifications included innovations which contributed positively to 
educational leadership preparation, including the creation of student cohorts within programs and enhanced university-school partnerships (McCarthy, 2015). In addition to improvement efforts at the programmatic level, individual states also undertook efforts to improve educational leadership preparation through state-level legislation and policy. Reform efforts differed by state with some states opting to offer alternative pathways to school leader licensure, while other states chose to augment educational leadership program structures and requirements (McCarthy, 2015). In Florida, where this study was completed, the William Cecil Golden Act of 2007 required educational leadership program redesigns across institutions in the state university system (Mountford \& Acker-Hocevar, 2013).

At the national level, the passage of ESSA in 2015 brought a renewed focus on educational leadership preparation, establishing a more encompassing notion of educational leadership and emphasizing the need to develop a "leadership pipeline" (Young et al., 2017, p. 705). Given this context, educational leadership program redesign and program impact received attention from scholars. Cosner (2019), in analyzing the process-orientation of exemplary programs, found that these programs used what they described as "impact logics" rather than responding to policy changes to engage in continuous improvement (p. 104). The process of continuous improvement in these exemplary programs constituted a holistic approach, which leveraged external resources (e.g., "impact data, leadership standards, research models, experts, and external funding"; Cosner, 2019, p. 106) and internal resources (e.g., "supportive program structures, data systems and internal program data, and leadership"; Cosner, 2019, p. 108). Young and Eddy-Spicer (2019) in an analysis of five programs that received UCEA's Exemplary Educational Leadership Preparation Program award, found that award-winning programs focused their continuous improvement efforts on what the researchers termed bridging, brokering, and 
bricolaging (p. 6). Bridging referred to the educational leadership's program ability to respond to the context germane to schools represented in their program; brokering referred to the demands of policy and efforts to "challenge the status quo" to resolve problems; and bricolaging referred to the creative, synergistic melding of resources and stakeholders to address issues (Young \& Eddy-Spicer, 2019, p. 7).

To determine the impact of educational leadership programs, researchers used qualitative analysis and student perceptions of program quality as the primary modes of investigation (Ni et al., 2017; Ni et al., 2019). However, there is research seeking to measure educational leadership preparation and its attending impact on principal performance (Grissom et al., 2019; Orphanos \& Orr, 2014). In a study of Tennessee principals' performance in their first three years, Grissom et al. (2019) found that principals' performance varied based on the outcome being measured (e.g., performance evaluations, student achievement outcomes). Grissom et al. (2019) noted that this finding made it difficult to identify which educational leadership programs prepared students well and which did not.

Orphanos and Orr (2014) found that principals who had completed an exemplary educational leadership program were rated highly by teachers in terms of leadership practices that supported teacher collaboration, leadership, and satisfaction when compared to peers who completed other educational leadership programs. Quantifying impact may the impetus for a focus on leadership assessment and development during educational leadership programs. In two separate studies, Orr and colleagues $(2018,2019)$ found that leadership assessment allowed for identification of students' various levels of leadership knowledge and skills as well as for assisting in the preparation of aspiring leaders and teacher leaders.

\section{Teacher Leadership}


To advance student academic outcomes, teachers must be part of the process of school improvement initiatives through leadership in those efforts (Barth, 2013; York-Barr \& Duke, 2004). Research on distributed leadership and collective leadership found that schools that provided leadership opportunities to teacher and other stakeholders have seen improved student academic outcomes (Leithwood \& Mascall, 2008; Chang, 2011). Teacher leadership exists in various forms in schools such as grade-level team leaders, content-area leaders, professional learning community leaders, and/or mentors. Further, teacher leaders also hold informal leadership roles grounded in their expertise (e.g., content area, pedagogical, or professional expertise), which their peers seek to inform their own practice (Fairman \& Mackenzie, 2015).

School improvement efforts and educational innovations have served as the impetus for school districts and schools to prepare teacher leaders (Carver, 2016; Gerstenschlager \& Barlow, 2019; Tahir et al., 2020). Teacher leadership research studies examined teacher leadership within professional learning communities (Wilson, 2016), teacher leadership approaches and qualities (Lai \& Cheung, 2015), including other teachers' perceptions of who was a teacher leader (Fairman \& Mackenzie, 2015). Within professional learning communities, teacher leadership was defined by teachers' classroom leadership with students and through teachers' responsibilities within the professional learning community structures (Wilson, 2016). Teacher leadership approaches included being active participants in school improvement efforts, learning through and collaborating in professional learning communities, and influencing peers to improve their instructional practice and serving as models (Lai \& Cheung, 2015). To be effective in teacher leadership, teacher leaders' influence on other teachers was based on teachers' perceptions that teacher leaders possessed instructional and content expertise, had a "range of experiences" in schools, and were willing to take risks (Fairman \& Mackenzie, 2015, p. 74). 
Ultimately, from teachers' point of view, teacher leadership rested on how student learning and organizational change was impacted by teacher leaders (Fairman \& Mackenzie, 2015).

Although most teacher leadership preparation efforts have been implemented at the school district and school level, university teacher preparation programs internationally and nationally are providing pre-service teachers with opportunities to engage in teacher leadership (Acquaro, 2019; Diamond, 2014; Nudrat \& Akhatar, 2014; Xu \& Patmor, 2012). Opportunities for teacher leadership development have been offered through service learning (Diamond, 2014) or through exploring teacher leadership case studies as part of the program curricula (Xu \& Patmor, 2012).

\section{Instructional Coach Leadership}

Similar to teacher leadership, instructional coaches' main purpose has been to contribute to teacher capacity-building efforts in schools (Jorissen et al., 2008; Mangin \& Dunsmore, 2015; Woulfin \& Rigby, 2017). Instructional coaches operate in formalized roles within schools where they are responsible for a range of tasks and duties, including data management, supporting subpopulations (i.e., English learners or special education) or providing instructional support (e.g., classroom observations, providing feedback, modeling lessons, etc.; Jorissen et al., 2008). In their efforts to contribute to overall school improvement and student outcomes, instructional coaches occupy a middle space between teachers and principals, where instructional coaches participate in goal setting with principals and are instrumental in working toward those school

goals (Jorissen et al., 2008; Woulfin \& Rigby, 2017). As instructional coaches collaborate with teachers, they contribute to both teacher instructional enhancements and overall teacher collective efficacy (Bryan \& Kaylor, 2018; Sweeney \& Mausbach, 2019). Orientations of instructional coaching like relationship-building and the provision of instructional support 
through expertise are critical to the school improvement efforts (Bryan \& Kaylor, 2018;

Campbell \& Malkus, 2013; Lowenhaupt et al., 2014). These orientations also were identified by Leithwood et al. (2020) as leadership practiced employed by successful school principals, underscoring the importance of the instructional coach role to school improvement and school outcomes.

Instructional coaching preparation has focused on building instructional expertise and relationship-building capabilities to advance student outcomes. Campbell and Malkus (2013) investigated mathematics instructional coaching preparation for elementary schools to determine the impact of trained mathematics coaches on student achievement. As part of the program curriculum investigated by the researchers, mathematics coaches completed two leadership courses where they learned to develop lessons that incorporated best practices, to engage in classroom observations, to complete pre- and post-observation conferences, to analyze student work samples, to develop professional learning, to work with adult learners, and to facilitate small-group and whole-group learning. Over a three-year period, schools with trained mathematics instructional coaches experienced positive changes in students' mathematics scores in Grades 3, 4, and 5 (Campbell \& Malkus, 2013).

As with teacher leadership preparation, university programs also participate in preparing instructional coaches for their roles. At the University of Kansas at Lawrence, instructional coaching preparation has focused on developing an adaptive coaching approach where instructional coaches modify their coaching based on the contexts of their schools (Knights, 2019). In this instructional coaching model, coaches are co-equal with teachers as they seek solutions and share expertise through conversations with teachers (Knight, 2019). The University of Florida Coaching Academy (n.d.), which offers seven different coaching preparation programs 
(e.g., instructional coaching, peer coaching, early childhood coaching, among others) to improve instructional practice, the programs are structured on: (a) high impact instruction, (b) instructional framework, (c) adult learning principles, (d) job-embedded leadership, (e) consistent and structured dialogue, and (f) inquiry and data driven solutions (p. 2).

\section{Central Office Leadership}

While the literature on teacher leaders and instructional coaches has focused on these group's capacity-building efforts within schools, the literature on central office (i.e., school district-level) leadership has focused on system-wide improvement efforts and the contributions of district personnel to systemic improvement. In a review of four major studies on the impact of school district-level leadership, Leon (2008) identified six trends among successful school district level leadership practices, which included leadership practices focusing on the vision, systems alignment, key priorities, collaboration, teaching and learning, and balancing autonomy (p. 55). The literature is clear that school district-level leadership practices are critical to school district efforts to improve school outcomes (Anderson et al., 2012; Honig et al., 2017). In addition to the role of the superintendent and other executive level leaders, there are other district level staff who lead and support efforts to improve teaching and learning, and subsequently have been included in school district-level leadership professional learning and core improvements efforts (Page, 2010).

School districts enact core improvements to teaching and learning through district staff, including school-based instructional coaches, school district-level instructional coaches, and school district-level leaders. In analyzing the work of school-based instructional coaches who formed networks to address educational reform, Galey-Horn (2020) determined that the collaboration between school-based instructional coaching networks and school district-level 
personnel supported the communication of the vision for school improvement and identification of professional learning needs necessary to effect change. In another study of school district improvement efforts through the introduction of digital one-to-one devices, Hashim (2020) concluded that district-level coaches needed district leadership support to coordinate efforts systematically across schools and to differentiate support based on school contexts.

As with teacher leaders and instructional coaches, relationship-building was also found to be a factor in school district-level leadership along with instructional and technical expertise. Leithwood et al. (2019), in an examination of school district characteristics that linked to student achievement outcomes, found that developing trust with teachers and among teachers advanced school district initiative implementation. As a mediating factor, the authors contended that trust facilitated the work toward the school district's vision and goals and supported collective teacher efficacy which led to teacher networks within the system.

School district and universities have formed partnerships to enhance school district leadership practices (Naicker \& Mestry, 2015). The authors described the Leadership for Learning Programme, a school district-university partnership, which included both principals and school district personnel. The framework constructed for the program included leadership and management, systems-thinking, systemic support, and data analysis and utilization each (Figure 1, p. 4). The researchers concluded that a systems-thinking orientation was necessary between principals and school district personnel predicated on relationships between these two groups and leading to collective capacity building. In short, for the entire system to be successful, the stakeholders engaged in systems coherence and organizational learning (Anderson et al., 2012; Leon, 2008).

\section{The Educational Leadership Program of Study}


The graduate educational leadership program used as the data source for this study is housed in a large public research university in Florida. Students enrolled in this educational leadership program come from the immediate geographical area and enroll in either a Master of Education, Specialist in Education, or Doctorate in Education to attain a state-level K-12 educational leadership licensure. The ELES was developed and delivered with in-person / face to face modality, except during the quick spring 2020 migration to remote instruction in response to COVID-19, which lasted through the end of 2020. In any of the three graduate programs, students will complete coursework aligned with Florida's Principal Leadership Standards (FPLS). Coursework includes organization and administration of schools and instructional programs; educational systems planning and management; legal and financial aspects of schools, teacher supervision and evaluation, data-based decision-making, and community relations. The program includes required clinical administrative experiences (i.e., internships) in local public schools. The professional roles of students who complete the program includes teachers at various levels of professional experience in the field, instructional coaches, academic deans, guidance counselors, and school district-level personnel (e.g., school-district level instructional coaches, school district-level administrators, and other non-executive positions).

Throughout the program, students are presented with learning tasks to engage students in authentic school-based leadership experiences aligned to the FPLS. For instance, in the databased decision-making courses, students work collaboratively to analyze existing student achievement data and develop plans to address student achievement gaps. In the teacher supervision and evaluation courses, students complete a teacher observation using their school district-approved teacher evaluation tool and collaborate with a teacher in a teacher-driven instructional coaching cycle. During the two field-based clinical experiences, students 
collaborate with a supervising principal to complete activities directly related to instructional leadership. To ensure that school districts needs are met through the learning tasks provided to students throughout the program, educational leadership program faculty host periodic meetings with school district partners to discuss school district leadership needs and to receive feedback on program completers' performance.

\section{Methods}

While the background, literature review, and theory well ground this research with the necessary foundation, the study capitalized on an existing voluntary exit survey that remains anonymous and open to graduate students exiting the program, who completed coursework to obtain educational leadership licensure. Graduate students complete the voluntary exit survey at the conclusion of the required field-based clinical experience. The institution's Institutional Review Board granted approval for this study to be conducted.

For this phase of the research, no interviews or focus groups were conducted. The method was quantitative and the design was casual comparative. There were two main research questions guiding this study: 1 . Is there a statistically significant difference among students' perceptions of the program coursework as having prepared them for educational leadership based on their professional roles? 2. Is there a statistically significant difference among students' perceptions of the program faculty facilitation of their learning and growth based on the professional role of the student?

\section{Sample and Instrumentation}

Researchers accessed post-hoc survey data from the exit survey for educational leadership graduate students seeking administrative licensure which spanned from August 5, 2013, through December 14, 2020. The total enrollment of MEd, EdS, and EdD graduate 
students in the program fluctuated during this time period because graduate students enter, drop out, stop out, return, and/or graduate. While there was a total of 2,700 students during these years, only 790 were new students. Enrollment per year including new students was as follows: $2013=334$ with 110 new, $2014=337$ with 115 new, 2015 = 326 with 92 new, $2016=327$ with 113 new, $2017=303$ with 96 new, $2018=294$ with 102 new, $2019=286$ with 89 new, and 2020 $=263$ with 73 new.

The survey was simply titled Educational Leadership Exit Survey (ELES) and consisted of 28 items. The ELES was developed by the department's faculty as one of many means of obtaining specific program effectiveness feedback from graduates. Internal consistency ratings for the items for research question 1 , student perceptions of the program preparing them for future leadership roles, yielded $(\alpha=.94)$ Cronbach's Alpha reliability statistic and $(\alpha=.92)$ for the items associated with research question 2 , student perceptions of faculty facilitating their learning and growth toward future leadership roles. The overall instrument score was $(\alpha=.96)$. Scores greater than .70 are generally considered reliable, in this case, very reliable. For the items 1 through 20, students rated their level of agreement with each of the statements regarding their program of study on a Likert-type scale, where possibilities for each answer were a range including $1=$ Strongly Disagree, $2=$ Disagree, $3=$ Agree, $4=$ Strongly Agree, and Not Applicable. All items on the survey refer to Educational Leadership faculty and programs, not to other courses or courses taught by non-educational leadership faculty. Items 21 through 28 referred to graduates' participation and experience in the TeachLive ${ }^{\mathrm{TM}}$ component of the educational leadership programs and students' background information. Analysis of items related to TeachLive ${ }^{\mathrm{TM}}$ are not included in this study. To determine the total available population using convenience sampling, we used the number of new students admitted to the program from 2013 
through $2020(N=790)$. Of that total available population, 410 respondents participated in online Qualtrics survey, yielding a 51.8\% response rate. However, only $(n=400) 50.6 \%$ completed enough of their surveys to be validly analyzed. In this case, convenience sampling was used because these surveys were available for download. There is an assumption that this sampling of respondents answered their survey items consistently and truthfully. There is also a limitation of the study caused by the sampling technique in that the sample may or may not be fully representative of the complete population leading to lower external reliability. As such, it is not recommended that this study's results be generalized beyond the sample, nor should results be ecologically generalized beyond this institution. However, replicating the study could "decrease the likelihood that the results obtained were simply a one-time occurrence" (Fraenkel et al., 2019, p. 100).

This current study used students' professional roles as the independent variable (IV). Roles were coded as: teachers $(n=247)$, instructional coaches $(n=53)$, administrators $(n=28)$, central office personnel $(n=23)$, and other $(n=46), 1-5$ respectively. The other category combined four roles: counselor $(n=2)$, other $(n=31)$, staffing specialist $(n=8)$, and data coach $(n=5)$. The administrators category included school district level administrators and charter school administrators, who did not possess administrative licensure. Central office personnel did not include school district level administrators. For the teachers category, a limitation of our sample was that we were unable to determine the teachers' leadership roles (e.g., department chair, professional learning community leader, etc.) in their schools. However, as part of the educational leadership program, all students complete learning tasks that require them to engage in authentic leadership activities. Therefore, participants categorized as teachers were treated as teacher leaders. 
The purpose of the current study was to identify if the educational leadership program was meeting the needs of each type of student based on their roles. This study sought to identify where the gaps in program effectiveness was, through the lens of the student in their professional roles, as indicated on the ELES. For example, it could be that the program was perceived as effective for teachers, but not effective for administrators or vice versa. Student perception scores (preparation and learning/growth) from the ELES represented the dependent variable (DV). Because the IV was not manipulated and measured categorically, the study design was causal comparative. The data met all of the assumptions necessary for conducting a One-Way ANOVA. The three groups in the sample were normally distributed (checked with Shapiro-Wilk test, histogram's skewness and kurtosis, no extreme outliers visible in box plots, and Normal Q-Q Plots), independence (three different groups were MEd, EdS, EdD), and had homogeneity of variance (Leven's $F$ test yielded a non-significant $p$ value). While ANOVA is robust to violations of normality, had extreme violations of the variance assumption occurred, then the alternative non-parametric Kruskal-Wallis test would have been used. The disadvantage of concluding an analysis immediately after running an ANOVA, is that the ANOVA only provides limited results and statistical significance may not be necessarily important. Therefore, a Tukey post-hoc analysis was utilized on three items to further verify specifically where the statistical significance lied.

\section{Data Analyses and Results}

Descriptive and inferential statistics were used to analyze the data in relation to the two research questions to facilitate a better understanding surrounding the student's perception of the program effectiveness. Mean and standard deviation central tendencies scores were calculated 
along with the ANOVA, which required at least one categorical and one continuous variable, hence the existing IV and DV.

\section{Educational Leadership Preparation Coursework and Professional Roles}

We began the analyses by examining overall student perceptions of the coursework in the educational leadership program through Items 1 through 11 of the ELES. Overall, student perceptions were slightly positive, mostly due to the high leptokurtosis on the response item "Agree" for most questions. The lowest student perception responses were for two items: "The information provided me by Educational Leadership faculty was accurate and up to date" (Item 6) and "Courses in the Educational Leadership Program were academically challenging" (Item 7) with a mean response of 3.74. The highest response was to the Item 10 "Student discussion and interactions were encouraged by instructors during class," $M=3.89$. Table 1 presents numbers of responses per item, response means, and response standard deviations for Items 1 through 11.

\section{<<Insert Table 1 about here〉>}

\section{Differences in Perceptions by Student Professional Roles}

Items 1 through 11 were analyzed using a one-way ANOVA to determine if there were differences in opinions among student professional roles at the time of ELES completion. While a majority of items had no statistically significant differences among groups based on their roles, there was a statistically significant difference, $F(5,391)=2.969, p=0.012$, for Item 7 "Courses in the Educational Leadership Program were academically challenging" among the administrators, instructional coaches, and central office personnel. The group that held the highest sentiment toward the academic challenge of the program was administrators, $M=4.00$, followed by instructional coaches, $M=3.87$. The group with the lowest opinion towards the 
academic challenge of the program were students who worked in the central office personnel, $M$ $=3.21$. Table 2 presents the results of Item 7 .

$<$ Insert Table 2 about here>>

The Tukey post-hoc analysis results signified that teachers $(n=247, M D=.547, p=$ $.014)$, instructional coaches $(n=53, M D=.654, p=.005)$, and administrators $(n=9, M D=$ $.786, p=.031)$ all scored this item significantly higher than central office personnel $(n=14, M=$ 3.21). This result indicates that school site-based personnel might be more likely to consider this program to be academically challenging than central office personnel. Table 3 presents the results of the Tukey post-hoc analysis.

$<<$ Insert Table 3 about here>>

\section{Educational Leadership Faculty Facilitation and Professional Roles}

Items 12 through 20 measured student perceptions of the faculty facilitation within the educational leadership program. As with the first research question, student sentiments were again slightly positive. The lowest student sentiment responses were for the item "Textbooks required for the courses were used on a regular basis," $M=3.53$. The highest response was to the item "Instructors expected students to be prepared for class presentation and discussions," $M=$ 3.92. Table 4 presents the number of responses per item, means, and standard deviations.

\section{$<<$ Insert Table 4 about here>>}

\section{Differences in Perceptions by Student Professional Roles}

Items 12 through 20 were analyzed using a one-way ANOVA to determine if there were differences in opinions between students when grouped by their professional roles at the time of survey completion. With a majority of items, there were no statistically significant differences 
between groups based on their roles; however, there were differences among professional roles on Items 13, 14, and 18.

First, Item 13 "The intellectual climate in the program was stimulating," there was a statistically significant difference between the groups, $F(5,388)=3.545, p=.004$. While the overall sentiment for all groups was still positive, central office personnel were more likely to neither agree nor disagree in comparison to school-based personnel who had more positive opinions of the intellectual climate of the program. The central office personnel group scored this item statistically significantly different from all the other groups except the administrators group.

Item 14, "The Educational Leadership faculty were supportive," there was a difference between the professional groups that was statistically significant, $F=2.860, p=0.015$. The group that perceived their faculty to be most supportive was instructional coaches $(n=53, M=$ 4.00) and the group with the lowest sentiment was site-based administrators $(n=9, M=3.44)$. While the overall model showed that there were statistically significant differences among groups, the Tukey post-hoc analysis did not demonstrate that an individual group differed statistically from any other single group.

On the perceptual statement regarding the use of curricular materials in Item 18, "Textbooks required for the courses were used on a regular basis," there was a statistically significant difference between the professional groups, $F(8,388)=2.510, p=.030$. On this item, the group that had the highest sentiment towards textbook usage was administrators $(n=9, M=$ 3.89) and the group with the lowest sentiment was students in the other category $(n=46, M=$ 3.26). A post-hoc analysis showed that the largest significant difference between groups was between instructional coaches and other $(M D=0.513, p=.023)$. Instructional coaches believed 
textbooks were used more often than students in the Other category. Table 5 presents the ANOVA results for Items 13, 14, and 18.

$<<$ Insert Table 5 about here〉>

While the overall ANOVA was statistically significant for Item 14, no interactions effects were noted in the Tukey post-hoc results. For Items 13 and 18, since significance was found, data within Table 6 yielded results of the Tukey post-hoc analysis to further verify specifically where the significance lied. For Item 13, the post-hoc analyses revealed that the role group that had the highest opinion of the intellectual climate was instructional coaches $(n=53, M=3.94)$, followed by school-based administrators $(n=9, M=3.89)$. The role groups with the lowest opinion of the program was central office personnel $(n=14, M=3.21)$. For Item 18 , it was in the Instructional Coaches compared to Others category.

<<Insert Table 6 about here〉>

\section{Discussion}

In the early 2000s, the perceived ineffectiveness of educational leadership programs to prepare future educational leaders lead to a focus on program improvements to enhance this group's preparation to contribute to PK-12 academic outcomes (Elmore, 2000, Hess \& Kelly, 2005; Lashway, 2003; Levine, 2005). In response, educational leadership preparation research focused on the components, processes, and learning experiences that contribute to quality educational leadership preparation (Anderson et al., 2018; Campanotta et al., 2018; Cosner, 2019; Cunningham \& Lochmiller, 2019; Cunningham et al., 2019; VanGronigen et al., 2018). As Young et al. (2017) described, ESSA established a broader concept of educational leadership and emphasized the need to develop the educational leadership pipeline. Educational leaders operate along a continuum, occupying quasi-leadership and traditional leadership roles. The goal of our 
study was to identify if the program was meeting the needs of students' professional roles (e.g., teachers, instructional coaches, administrators, and central office personnel), that is, the roles along the leadership continuum. By using the ELES exit survey and analyzing those data, we sought to identify where the gaps in program effectiveness existed based on students' professional roles.

\section{Perceptual Differences Among Students' Professional Roles}

Our overall analysis of student survey data suggested that in the aggregate, the educational leadership program of study was meeting student needs. However, results of the ANOVAs indicated perceptual differences among professional roles represented in educational leadership program of study in terms of a challenging academic program, stimulating intellectual climate, supportive faculty, and use of curricular materials (i.e., textbooks). Among the roles represented in our study, administrators and instructional coaches demonstrated a higher perception of the academic challenge of the program and stimulating intellectual climate, while central office personnel demonstrated a lower perception. The differences found may lie in the work focus of administrators and instructional coaches versus the work focus of central office personnel. As school-based personnel, administrators and instructional coaches are more likely to collaborate with individual teachers or groups of teachers on instructional improvements. Therefore, administrators and instructional coaches in educational leadership preparation programs may perceive developmental benefits to their instructional expertise, including school goal setting and implementation, provision of support to teachers, and overall contributions to site-based school improvement efforts (Bryan \& Kaylor, 2018; Campbell \& Malkus, 2013; Hopkins et al., 2013; Jorissen et al., 2008; McCarthy, 2015; Robinson et al., 2008; Sweeney \& Mausbach, 2019; Woulfin \& Rigby, 2017). 
Central office personnel, on the other hand, may be more accustomed to macro-level school district and/or state-wide complex issues that are perplexing and must be resolved, sometimes rapidly, for the sake of the entire school district or the school. To enhance the leadership preparation of central office personnel, there may be a need to include learning experiences on systemic teaching and learning improvement efforts across an entire school district, groups of schools within a school district, or across a school (Anderson et al., 2012; Honig et al., 2017). These learning experiences should also highlight effective collaboration mechanisms between school districts and schools to support systemic improvement efforts (Galey-Horn, 2020; Page, 2010). In short, to prepare all leaders represented in educational leadership programs effectively, it may prove beneficial to review course syllabi and learning tasks to ensure students in varying professional roles have access to differentiated powerful learning experiences (Cunningham et al., 2019; Young, 2015), which connect the curriculum to current and future professional contexts of students (Young \& Eddy-Spicer, 2019).

Perceptual differences related to supportive faculty revealed that instructional coaches were also the most prone to perceive that faculty were supportive, while administrators had the lowest perception of support. This difference in perceptions may be due to the focus of this educational leadership program on the development of future administrators due to state-level requirements (Mountford \& Acker-Hocevar, 2013) rather than to further development of inservice administrators. It is important to note that administrators enrolled in this program were either school-district administrators or charter school administrators. As in-service administrators continue to seek educational leadership preparation, learning experiences may need to be added to the curriculum to address their needs to further support this professional group (Levine, 2005). 
While administrators perceived lower perceptions of faculty support, they held a higher perception of the use of curricular materials in classes. This difference may be due to administrators' individual usage of curricular materials to enhance their own learning. Interestingly, instructional coaches were prone to both higher perceptions of faculty support and use of curricular materials. It may be that the learning experiences and curricular in courses along with faculty support and facilitation were well suited to providing both "curricular coherence" and "curricular balance" (Levine, 2005, p. 13) for instructional coaches.

\section{Conclusion}

As schools become increasingly more complex organizations, requiring distribution of responsibility for educational reform initiatives among various levels of leadership, this novel approach to examine educational leadership program effectiveness, may further assist in educational improvement efforts. The differences found among the professional roles represented in this educational leadership program highlight potential implications for policy, practice, and for future research. In terms of potential implications for policy, national- and statelevel organizations that create standards for educational leadership preparation programs may consider the full continuum of leadership roles represented in educational leadership programs as they develop or revise standards. Explicitly acknowledging the leadership preparation of these groups in leadership standards may provide a framework for addressing the leadership needs of various roles along the continuum for all who rely on leadership standards to guide continuous improvement. Potential implications for practice for educational leadership programs may include building upon existing university-school partnerships by collaborating with school district partners on leadership needs analyses beyond the leadership needs of the principalship and enhancing curricula to meet the identified leadership needs. As seen in the literature, school 
districts provide professional learning to teacher leaders, instructional coaches, and central office personnel as part of comprehensive educational reform efforts. Educational leadership programs are valued partners in the change process within complex educational systems. As such, educational leadership programs could advance the work of school districts within the framework of educational leadership preparation curricula by increasing the scope of leadership preparation to include multiple leadership roles and collaboration among roles.

Lastly, further research in this area is greatly needed. The differences in perceptions among the professional roles represented in this educational leadership program highlighted the need for further investigation. While this study spanned a seven-year period and was comprised of a decent sample size, the study's findings are limited. Findings from this research study are a first step that may point to a need for further analysis using a qualitative design to further contextualize the results of the statistical analysis (Creswell \& Plano Clark, 2018). Future targeted studies using focus groups and/or interviews could facilitate a better understanding of the significant differences. A thorough qualitative study could further unpack the findings in this study, yielding important results that could inform educational leadership preparation to better serve the roles along the leadership continuum. For instance, focus group and/or interview research could focus on inviting students representing the various professional roles in educational leadership programs and could explore students' perceptions of the contributions of program faculty, structure, and curricula on their current and future leadership competencies. By diving deeply into students' program experience, a qualitative study could uncover faculty approaches, program implementation, and learning experiences deemed important and timely to school improvement efforts by teacher leaders, instructional coaches, and central office personnel. The detailed insights gained through a qualitative study could allow for further 
comparisons among the student professional groups to determine where leadership competencies align and where differentiation is needed to best meet the needs of all professional roles. In addition to qualitative studies, more quantitative studies are needed to determine perceptions of effectiveness among student professional roles in other educational leadership preparation programs.

\section{References}

Acquaro, D. (2019). Preparing the next generation of educational leaders: Initiating a leadership discourse in initial teacher education. Commonwealth Council for Educational Administration and Management (CCEAM), 47(2), 107-124. https://csse-scee.ca/wpcontent/uploads/2019/12/ISEA_2019_472.pdf\#page=113

Anderson, E., Winn, K. M., Young, M. D., Groth, C., Korach, S., Pounder, D., \& Rorrer, A. K. (2018). Examining university leadership preparation: An analysis of program attributes and practices. Journal of Research on Leadership Education, 13(4), 375-397. https://doi.org/10.1177\%2F1942775117735873

Anderson, S. E., Mascall, B., Stiegelbauer, S., \& Park, J. (2012). No one way: Differentiating school district leadership and support for school improvement. Journal of Educational Change, 13(4), 403-430. https://doi.org/10.1007/s10833-012-9189-y

Archbald, D. (2016). System-level instructional leadership - A district-level leadership case: Implementing PLCs in schools. International Journal of Educational Leadership Preparation, 11(2), 116-151. https://files.eric.ed.gov/fulltext/EJ1124011.pdf 
Barth, R. S. (2013). The time is ripe (again). Educational Leadership, 71(2), 10-16. http://www.ascd.org/publications/educational-leadership/oct13/vol71/num02/The-TimeIs-Ripe-(Again).aspx

Bertrand, M., \& Rodela, K. C. (2018). A framework for rethinking educational leadership in the margins: Implications for social justice leadership preparation. Journal of Research on Leadership Education, 13(1), 10-37. https://doi.org/10.1177\%2F1942775117739414

Bogler, R., \& Nir, A. E. (2015). The contribution of perceived fit between job demands and abilities to teachers' commitment and job satisfaction. Educational Management Administration \& Leadership, 43(4), 541-560. https://doi.org/10.1177\%2F1741143214535736

Bryan, C., \& Kaylor, B. (2018). Building blocks of collaboration. The Learning Professional, 39(6), 54-60. https://learningforward.org/wp-content/uploads/2018/12/building-blocksof-collaboration.pdf

Campanotta, L., Simpson, P., \& Newton, J. (2018). Program quality in leadership preparation programs: An assessment tool. Education, 138(3), 219-228.

Campbell, P. F., \& Malkus, N. N. (2013). Elementary mathematics specialists: Influencing student achievement. Teaching Children Mathematics, 20(3), 198-205. https://www.jstor.org/stable/10.5951/teacchilmath.20.3.0198

Carver, C. L. (2016). Transforming identities: The transition from teacher to leader during teacher leader preparation. Journal of Research on Leadership Education, 11(2), 158180. https://doi.org/10.1177\%2F1942775116658635 
Ceballos, M., Buckridge, H., \& Taylor, R. T., (2020). Educational leadership students and mixed reality experiences: Building student confidence to communicate with parents and teachers. International Journal of Educational Leadership Preparation, 15(1), 58-71.

Ceballos, M., Eadens, D.W., \& Bixler, K. (in press). Mixed reality and school administrator preparation: Harnessing the power of simulation technology for realistic practice, feedback, and reflection. In S.D. Hayes, N.A. Abdelrahman, B. J. Irby \& F. Nafukho (Eds.), School principals as talent developers: An international perspective. Information Age.

Chang, I. H. (2011). A study of the relationships between distributed leadership, teacher academic optimism and student achievement in Taiwanese elementary schools. School Leadership \& Management, 31(5), 491-515. https://doi.org/10.1080/13632434.2011.614945

Clayton, J. K., Sanzo, K. L., \& Myran, S. (2013). Understanding mentoring in leadership development: Perspectives of district administrators and aspiring leaders. Journal of Research on Leadership Education, 8(1), 77-96. https://doi.org/10.1177\%2F1942775112464959

Cosner, S. (2019). What makes a leadership preparation program exemplary? Journal of Research on Leadership Education, 14(1), 98-115. https://doi.org/10.1177\%2F1942775118819661

Cosner, S., Tozer, S., Zavitkovsky, P., \& Whalen, S. P. (2015). Cultivating exemplary school leadership preparation at a research intensive university. Journal of Research on Leadership Education, 10(1), 11-38. https://doi.org/10.1177\%2F1942775115569575 
Creswell, J. W., \& Plano Clark, V. (2018). Designing and conducting mixed methods research ( $3^{\text {rd }}$ ed.). SAGE.

Cunningham, K. M., \& Lochmiller, C. R. (2019). Content-specific leadership: Identifying literature-based implications for principal preparation. Journal of Research on Leadership Education. https://doi.org/10.1177/1942775119845004

Cunningham, K. M., VanGronigen, B. A., Tucker, P. D., \& Young, M. D. (2019). Using powerful learning experiences to prepare school leaders. Journal of Research on Leadership Education, 14(1), 74-97. https://doi.org/10.1177\%2F1942775118819672

Diamond, A. (2014). Pre-service early childhood educators' leadership development through reflective engagement with experiential service learning and leadership literature. Australasian Journal of Early Childhood, 39(4), 12-20. https://doi.org/10.1177\%2F183693911403900403

Dolph, D. (2017). Challenges and opportunities for school improvement: Recommendations for urban school principals. Education and Urban Society, 49(4), 363-387. https://doi.org/10.1177/0013124516659110

Duke, D. L. (2019). Judgment and the preparation of educational leaders. Journal of Research on Leadership Education, 14(3), 191-211. https://doi.org/10.1177\%2F1942775117752455

Elmore, R. F. (2000). Building a new structure for school leadership. The Albert Shanker Institute https://files.eric.ed.gov/fulltext/ED546618.pdf

Fairman, J. C., \& Mackenzie, S. V. (2015). How teacher leaders influence others and understand their leadership. International Journal of Leadership in Education, 18(1), 61-87. https://doi.org/10.1080/13603124.2014.904002 
Fraenkel, J. R., Wallen, N. E., \& Hyun, H. H. (2019). How to design and evaluate research in education, $10^{\text {th }}$ Edition. McGraw Hill.

Galey-Horn, S. (2020). Capacity-building for district reform: The role of instructional-coach teams. Teachers College Record, 122(10), 100303. https://www.tcrecord.org/Content.asp?ContentId=23443

Gerstenschlager, N. E., \& Barlow, A. T. (2019). Transitioning from practicing teacher to teacher leader: A case study. Teacher Development, 23(1), 18-35. https://doi.org/10.1080/13664530.2018.1515106

Grissom, J. A., Mitani, H., \& Woo, D. S. (2019). Principal preparation programs and principal outcomes. Educational Administration Quarterly, 55(1), 73-115. https://doi.org/10.1177\%2F0013161X18785865

Harris, A., \& Spillane, J. (2008). Distributed leadership through the looking glass. Management in Education, 22(1), 31-34. https://doi.org/10.1177\%2F0892020607085623

Hashim, A. K. (2020). Coaching and districtwide improvement: Exploring the systemic leadership practices of instructional coaches. Teachers College Record, 122(10), 100305. https://www.tcrecord.org/Content.asp?ContentId=23439

Hattie, J.A.C. (2009). Visible learning: A synthesis of 800+ meta-analyses on achievement. London: Routledge.

Hayes, S. D., \& Irby, B. J. (2019). Challenges in preparing aspiring principals for instructional leadership: Voices from the field. International Journal of Leadership in Education, 121. https://doi.org/10.1080/13603124.2018.1562102 
Hess, F. M., \& Kelly, A. P. (2005). An innovative look, a recalcitrant reality: the politics of principal preparation reform. Educational Policy, 19(1), 155-180. https://doi.org/10.1177/0895904804270776

Hollingworth, L., Olsen, D., Asikin-Garmager, A., \& Winn, K. M. (2018). Initiating conversations and opening doors: How principals establish a positive building culture to sustain school improvement efforts. Educational Management Administration \& Leadership, 46(6), 1014-1034. https://doi.org/10.1177/1741143217720461

Honig, M. I., Venkateswaran, N., \& McNeil, P. (2017). Research use as learning: The case of fundamental change in school district central offices. American Educational Research Journal, 54(5), 938-971. https://doi.org/10.3102\%2F0002831217712466

Hopkins, M., Spillane, J. P., Jakopovic, P., \& Heaton, R. M. (2013). Infrastructure design and instructional reform in mathematics: Formal structure and teacher leadership. The Elementary School Journal, 114(2), 200-224. https://doi.org/10.1086/671935

Ingle, W. K., Marshall, J. M., \& Hackmann, D. G. (2018). The leaders of leadership preparation programs: A study of program coordinators at UCEA-member institutions. Journal of Research on Leadership Education. https://doi.org/10.1177/1942775118803334

Johnson, A. D., \& James, S. (2018). Principal and professor perspectives on principal preparation, program redesign, and educational planning. Educational Planning, 25(3), 19-30. https://files.eric.ed.gov/fulltext/EJ1207945.pdf

Jorissen, K. T., Salazar, P., Morrison, H., \& Foster, L. (2008). Instructional coaches: Lessons from the field. Principal Leadership, 9(2), 16-19. https://securemedia.collegeboard.org/digitalServices/pdf/advocacy/M7_R5_PLOct08_p16-19.pdf 
Knight, J. (2019). Instructional coaching for implementing visible learning: A model for translating research into practice. Education Sciences, 9(2), 101. https://doi.org/10.3390/educsci9020101

Lai, E., \& Cheung, D. (2015). Enacting teacher leadership: The role of teachers in bringing about change. Educational Management Administration \& Leadership, 43(5), 673-692. https://doi.org/10.1177\%2F1741143214535742

Lashway, L. (2003). Transforming principal preparation. ERIC Digest. https://files.eric.ed.gov/fulltext/ED473360.pdf

Leithwood, K. A., \& Riehl, C. (2003). What we know about successful school leadership. Philadelphia, PA: Laboratory for Student Success, Temple University Press. http://olms.cte.jhu.edu/olms2/data/ck/file/What_we_know_about_SchoolLeadership.pdf

Leithwood, K., \& Mascall, B. (2008). Collective leadership effects on student achievement. Educational Administration Quarterly, 44(4), 529-561. https://doi.org/10.1177\%2F0013161X08321221

Leithwood, K., Harris, A., \& Hopkins, D. (2020). Seven strong claims about successful school leadership revisited. School Leadership \& Management, 40(1), 5-22. https://doi.org/10.1080/13632434.2019.1596077

Leithwood, K., Sun, J., \& McCullough, C. (2019). How school districts influence student achievement. Journal of Educational Administration, 57(5), 519-539. https://doi.org/10.1108/JEA-09-2018-0175

Leon, R. (2008). District office leadership: Hero or villain? CAPEA Educational Leadership and Administration, 20, 46-56. https://files.eric.ed.gov/fulltext/EJ965133.pdf 
Levine, A. (2005). Educating school leaders. The Education Schools Project. http://edschools.org/pdf/Final313.pdf

Lowenhaupt, R., McKinney, S., \& Reeves, T. (2014). Coaching in context: The role of relationships in the work of three literacy coaches. Professional Development in Education, 40(5), 740-757. https://doi.org/10.1080/19415257.2013.847475

Mangin, M. M., \& Dunsmore, K. (2015). How the framing of instructional coaching as a lever for systemic or individual reform influences the enactment of coaching. Educational Administration Quarterly, 51(2), 179-213. https://doi.org/10.1177\%2F0013161X14522814

McAdamis, S. (2010). Central office and school leaders create a conversation. The Learning Professional, 31(3), 24-27. https://www.proquest.com/scholarly-journals/central-officeschool-leaders-create-conversation/docview/870834142/se-2?accountid=10003

McCarthy, M. (2015). Reflections on the evolution of educational leadership preparation programs in the United States and challenges ahead. Journal of Educational Administration, 53(3), 416-438. https://doi.org/10.1108/JEA-03-2014-0045

Mette, I. M., \& Scribner, J. P. (2014). Turnaround, transformational, or transactional leadership: An ethical dilemma in school reform. Journal of Cases in Educational Leadership, 17(4), 3-18. https://doi.org/10.1177\%2F1555458914549665

Miller, R. J., Wargo, E., \& Hoke, I. (2019). Instructional coaching: Navigating the complexities of leadership. Journal of Cases in Educational Leadership, 22(3), 16-27. https://doi.org/10.1177\%2F1555458919848134 
Mountford, M., \& Acker-Hocevar, M. A. (2013). Florida's mandated educational leadership program redesign: The William Cecil golden touch. Journal of Research on Leadership Education, 8(2), 212-229. https://doi.org/10.1177/1942775113491261

Mullen, C. A., \& Eadens, D.W. (2018). "Quality leadership matters": A research-based survey of graduate programming. Journal of Research on Leadership Education, 13(2), 162-200. https://doi.org/10.1177\%2F1942775117739415

Murphy, J., \& Vriesenga, M. (2006). Research on school leadership preparation in the United States: An analysis. School Leadership and Management, 26(2), 183-195. https://doi.org/10.1080/13634230600589758

Naiker, S. R., \& Mestry, R. (2015). Developing educational leaders: A partnership between two universities to bring about system-wide change. South African Journal of Education, 35(2), 1-11. https://doi.org/10.15700/saje.v35n2a1085

New Leaders. (2018, January). Prioritizing leadership: Opportunities in Every Student Succeed Act. https://www.newleaders.org/prioritizing-leadership-essa

Nettles, S. M., \& Herrington, C. (2007). Revisiting the importance of the direct effects of school leadership on student achievement: The implications for school improvement policy. Peabody Journal of Education, 82(4), 724-736. https://doi.org/10.1080/01619560701603239

Ni, Y., Hollingworth, L., Rorrer, A., \& Pounder, D. (2017). The evaluation of educational leadership preparation programs. In M. D. Young \& G. M. Crow (Eds.), Handbook of research on the education of school leaders (2nd ed., pp. 285-307). New York, NY: Routledge. https://doi.org/10.4324/9781315724751 
Ni, Y., Rorrer, A. K., Pounder, D., Young, M., \& Korach, S. (2019). Leadership matters: Preparation program quality and learning outcomes. Journal of Educational Administration, 57(2), 185-206. https://doi.org/10.1108/JEA-05-2018-0093

Nudrat, F., \& Akhtar, M. S. (2014). Assessing potential for teacher leadership: The case of prospective teachers. Journal of Research \& Reflections in Education (JRRE), 8(2), 105115.

Orphanos, S., \& Orr, M. T. (2014). Learning leadership matters: The influence of innovative school leadership preparation on teachers' experiences and outcomes. Educational Management Administration \& Leadership, 42(5), 680-700. https://doi.org/10.1177\%2F1741143213502187

Orr, M. T. (2011). Pipeline to preparation to advancement: Graduates' experiences in, through, and beyond leadership preparation. Educational Administration Quarterly, 47(1), 114172. https://doi.org/10.1177\%2F0011000010378612

Orr, M. T., \& Orphanos, S. (2011). How graduate-level preparation influences the effectiveness of school leaders: A comparison of the outcomes of exemplary and conventional leadership preparation programs for principals. Educational Administration Quarterly, 47(1), 18-70. https://doi.org/10.1177\%2F0011000010378610

Orr, M. T., Hollingworth, L., \& Beaudin, B. (2019). Performance assessment for school leaders: Comparing field trial and implementation results. Journal of Educational Administration. Retrieved from https://doi.org/10.1108/JEA-05-2018-0087

Orr, M. T., Hollingworth, L., \& Cook, J. (2018). Embedding performance assessments for leaders into preparation: A comparison of approaches, candidates, and assessment 
evidence. Journal of School Leadership, 28(3), 294-314.

https://doi.org/10.1177\%2F105268461802800302

Page, D. (2010). Systemic efforts in Georgia to improve education leadership. Performance Improvement, 49(3), 11-16. https://doi.org/10.1002/pfi.20132

Perrone, F., \& Tucker, P. D. (2019). Shifting profile of leadership preparation programs in the 21st century. Educational Administration Quarterly, 55(2), 253-295. https://doi.org/10.1177\%2F0013161X18799473

Riley, D. L., \& Meredith, J. (2017). State efforts to strengthen school leadership: Insights from CCSSO action groups. Washington, DC: Policy Studies Associates. https://files.eric.ed.gov/fulltext/ED580215.pdf

Robinson, V. M. J., Lloyd, C. A., Rowe, K. J. (2008). The impact of leadership on student outcomes: an analysis of differential effects of leadership types. Educational Administration Quarterly, 44(5), 635-674. https://doi.org/10.1177/0013161X08321509

Spillane, J. (2005). Distributed leadership. The Educational Forum, 69(2), 143-150. https://doi.org/10.1080/00131720508984678

Sweeney, D., \& Mausbach, A. (2019). Creating powerful principal and coach partnerships. Educational Leadership, 76(6), 30-35. http://www.ascd.org/publications/educationalleadership/mar19/vol76/num06/Creating-Powerful-Principal-and-CoachPartnerships.aspx

Tahir, L. M., Musah, M. B., Al-Hudawi, S. H. V., \& Daud, K. (2020). Becoming a teacher leader: Exploring Malaysian in-service teachers' perceptions, readiness and challenges. Education and Science, 45(202), 283-310. DOI: 10.15390/EB.2020.7362 
Tingle, E., Corrales, A., \& Peters, M. L. (2019). Leadership development programs: Investing in school principals. Educational Studies, 45(1), 1-16.

https://doi.org/10.1080/03055698.2017.1382332

University of Florida Coaching Academy. (n.d.). University of Florida Lastinger Center for Learning. http://lastingercenter.com/wpcontent/uploads/2015/09/CoachingAcademy2015Ver41.pdf

VanGronigen, B. A., Cunningham, K. M., \& Young, M. D. (2018). How exemplary educational leadership preparation programs hone the interpersonal-intrapersonal (i2) skills of future leaders. Journal of Transformative Leadership \& Policy Studies, 7(2), 1-11. https://doi.org/10.36851/jtlps.v7i2.503

Wilson, A. (2016). From professional practice to practical leader: Teacher leadership in professional learning communities. International Journal of Teacher Leadership, 7(2), 45-62. https://files.eric.ed.gov/fulltext/EJ1137497.pdf

Woulfin, S. L., \& Rigby, J. G. (2017). Coaching for coherence: How instructional coaches lead change in the evaluation era. Educational Researcher, 46(6), 323-328. https://www.jstor.org/stable/44972472

Woulfin, S.L. (2018). Mediating instructional reform: An examination of the relationship between district policy and instructional coaching. AERA Open, 4(3), 1-16. https://doi.org/10.1177/2332858418792278

Xu, Y., \& Patmor, G. (2012). Fostering leadership skills in pre-service teachers. International Journal of Teaching and Learning in Higher Education, 24(2), 252-256. https://files.eric.ed.gov/fulltext/EJ996270.pdf 
York-Barr, J., \& Duke, K. (2004). What do we know about teacher leadership? Findings from two decades of scholarship. Review of Educational Research, 74(3), 255-316. https://doi.org/10.3102\%2F00346543074003255

Young, M. D. (2015). The leadership challenge: Supporting the learning of all students. Leadership and Policy in Schools, 14(4), 389-410. https://doi.org/10.1080/15700763.2015.1073330

Young, M. D., \& Eddy-Spicer, D. H. (2019). Bridging, brokering, bricolage: Building exemplary leadership programs from the inside out. Journal of Research on Leadership Education, 14(1), 3-10. https://doi.org/10.1177\%2F1942775118820129

Young, M. D., Winn, K. M., \& Reedy, M. A. (2017). The Every Student Succeeds Act: Strengthening the focus on educational leadership. Educational Administration Quarterly, 53(5), 705-726. https://doi.org/10.1177\%2F0013161X17735871 
Table 1

Overall Student Perception of Educational Leadership Coursework $(N=408)$

\begin{tabular}{lccc}
\hline \multicolumn{1}{c}{ Survey Item } & $n$ & $M$ & $S D$ \\
\hline $\begin{array}{l}\text { 1. Course content assisted me in being more effective } \\
\text { as an educator }\end{array}$ & 408 & 3.84 & .556 \\
$\begin{array}{l}\text { 2. Course content was drawn from research and } \\
\text { contemporary literature. }\end{array}$ & 408 & 3.84 & .591 \\
$\begin{array}{l}\text { 3. I received frequent feedback from my instructors } \\
\text { on my progress in class. }\end{array}$ & 408 & 3.75 & .617 \\
$\begin{array}{l}\text { 4. Educational Leadership faculty were available } \\
\text { outside of class time. }\end{array}$ & 407 & 3.78 & .672 \\
$\begin{array}{l}\text { 5. Educational Leadership faculty set high } \\
\text { expectations for student performance. }\end{array}$ & 408 & 3.84 & .578 \\
$\begin{array}{l}\text { 6. The information provided to me by Educational } \\
\text { Leadership faculty was accurate and up to date. }\end{array}$ & 408 & 3.74 & .643 \\
$\begin{array}{l}\text { 7. Courses in the Educational Leadership Program } \\
\text { were academically challenging. }\end{array}$ & 408 & 3.74 & .640 \\
$\begin{array}{l}\text { 8. The administrative internship prepared me to } \\
\text { apply for entry level leadership positions. }\end{array}$ & 408 & 3.78 & .666 \\
$\begin{array}{l}\text { 9. The number of students in the classes I took was } \\
\text { appropriate for graduate level courses. }\end{array}$ & 406 & 3.87 & .622 \\
$\begin{array}{l}\text { 10. Student discussion and interactions were } \\
\text { encouraged by instructors during class. }\end{array}$ & 405 & 3.89 & .618 \\
$\begin{array}{l}\text { 11. The administrative internship was a valuable } \\
\text { learning experience. }\end{array}$ & 398 & 3.82 & .621 \\
\hline
\end{tabular}

Note. Number of participant responses vary by item.

\section{Table 2}

ANOVA Results: Academically Challenging Program and Stimulating Intellectual Climate

\begin{tabular}{|c|c|c|c|c|c|c|c|}
\hline & & \multirow[b]{2}{*}{$\begin{array}{l}\text { Sum of } \\
\text { Squares }\end{array}$} & \multirow{2}{*}{\multicolumn{3}{|c|}{ Mean }} & \multirow[b]{2}{*}{ Sig. } \\
\hline & & & & & & & \\
\hline \multirow[t]{4}{*}{7.} & \multirow{4}{*}{$\begin{array}{l}\text { Courses in the } \\
\text { Educational } \\
\text { Leadership Program } \\
\text { were academically } \\
\text { challenging. }\end{array}$} & Between groups & 5.480 & & & 60 & $012 *$ \\
\hline & & Within groups & 144.329 & 5 & & 2.969 & $.012^{*}$ \\
\hline & & & & 391 & 0.369 & & \\
\hline & & Total & 149.809 & 396 & & & \\
\hline
\end{tabular}

Note: ${ }^{*} p<.05$ 
Table 3

Tukey Post-Hoc: Academically Challenging Courses

\begin{tabular}{|c|c|c|c|c|c|c|c|}
\hline & $\begin{array}{c}\text { Current } \\
\text { Role }\end{array}$ & Current Role & $\begin{array}{c}\text { Mean } \\
\text { Difference }\end{array}$ & $\begin{array}{l}\text { Std. } \\
\text { Error }\end{array}$ & Sig. & \multicolumn{2}{|c|}{$\begin{array}{l}\text { 95\% Confidence } \\
\text { Interval }\end{array}$} \\
\hline Dependent & & & & & & Lower & Upper \\
\hline Variable & & & & & & Bound & Bound \\
\hline 7. Courses in & Central & Teacher & -.547 & .167 & $.014^{*}$ & -1.02 & -.07 \\
\hline $\begin{array}{l}\text { the } \\
\text { Educational }\end{array}$ & Office & $\begin{array}{l}\text { Instructional } \\
\text { Coach }\end{array}$ & -.654 & .183 & $.005 *$ & -1.18 & -.13 \\
\hline Leadership & & Dean & -.536 & .199 & .079 & -1.11 & .03 \\
\hline Program were & & Administrator & -.786 & .260 & $.031 *$ & -1.53 & -.04 \\
\hline $\begin{array}{l}\text { academically } \\
\text { challenging. }\end{array}$ & & Other & -.481 & .185 & .101 & -1.01 & .05 \\
\hline
\end{tabular}

Table 4

Overall Student Perceptions of Faculty Facilitation of Learning $(N=408)$

\begin{tabular}{|c|c|c|c|}
\hline Survey Item & $n$ & $M$ & $S D$ \\
\hline $\begin{array}{l}\text { 12. Instructors expected students to be prepared for } \\
\text { class presentations and discussion. }\end{array}$ & 398 & 3.92 & .555 \\
\hline $\begin{array}{l}\text { 13. The intellectual climate in the program was } \\
\text { stimulating. }\end{array}$ & 398 & 3.82 & .601 \\
\hline $\begin{array}{l}\text { 14. The Educational Leadership faculty were } \\
\text { supportive. }\end{array}$ & 397 & 3.82 & .612 \\
\hline $\begin{array}{l}\text { 15. The Educational Leadership Program adequately } \\
\text { prepared me for the Florida Educational Leadership } \\
\text { Examination. }\end{array}$ & 398 & 3.78 & .666 \\
\hline $\begin{array}{l}\text { 16. The program prepared me for my professional } \\
\text { career goals. }\end{array}$ & 398 & 3.80 & .606 \\
\hline $\begin{array}{l}\text { 17. Courses were offered frequently enough for } \\
\text { timely completion of the program. }\end{array}$ & 398 & 3.67 & .747 \\
\hline $\begin{array}{l}\text { 18. Textbooks required for the courses were used on a } \\
\text { regular basis. }\end{array}$ & 398 & 3.53 & .817 \\
\hline $\begin{array}{l}\text { 19. Student interactions and discussions added to the } \\
\text { quality of the courses. }\end{array}$ & 398 & 3.86 & .616 \\
\hline $\begin{array}{l}\text { 20. Electronic databases were useful in completing } \\
\text { the program requirements. }\end{array}$ & 398 & 3.77 & .702 \\
\hline
\end{tabular}


Note. Number of participant responses vary by item.

Table 5

ANOVA Results: Supportive Faculty and Textbook Usage

\begin{tabular}{|c|c|c|c|c|c|c|}
\hline & & $\begin{array}{l}\text { Sum of } \\
\text { Squares }\end{array}$ & df & $\begin{array}{l}\text { Mean } \\
\text { Square }\end{array}$ & $F$ & Sig. \\
\hline \multirow{3}{*}{$\begin{array}{l}\text { 13. The intellectual } \\
\text { climate in the program } \\
\text { was stimulating. }\end{array}$} & Between groups & 6.240 & 5 & 1.248 & 3.545 & $.004 * *$ \\
\hline & Within groups & 136.603 & 388 & 0.352 & & \\
\hline & Total & 142.843 & 393 & & & \\
\hline \multirow{3}{*}{$\begin{array}{l}\text { 14. The Educational } \\
\text { Leadership faculty were } \\
\text { supportive. }\end{array}$} & Between groups & 5.258 & 5 & 1.052 & 2.860 & $.015^{*}$ \\
\hline & Within groups & 142.274 & 387 & .368 & & \\
\hline & Total & 147.532 & 392 & & & \\
\hline \multirow{3}{*}{$\begin{array}{l}\text { 18. Textbooks required } \\
\text { for the courses were used } \\
\text { on a regular basis. }\end{array}$} & Between groups & 8.280 & 5 & 1.656 & 2.510 & $.030^{*}$ \\
\hline & Within groups & 255.966 & 388 & .660 & & \\
\hline & Total & 264.246 & 393 & & & \\
\hline
\end{tabular}

Note: $* p<.05, * * p<.01$

Table 6

Tukey Post-Hoc: Intellectual Climate and Textbooks Required Regularly

\begin{tabular}{|c|c|c|c|c|c|c|c|}
\hline & $\begin{array}{l}\text { Independent } \\
\text { Variable }\end{array}$ & Current Role & $\begin{array}{c}\text { Mean } \\
\text { Difference }\end{array}$ & $\begin{array}{l}\text { Std. } \\
\text { Error }\end{array}$ & Sig. & \multicolumn{2}{|c|}{$\begin{array}{c}\text { 95\% Confidence } \\
\text { Interval }\end{array}$} \\
\hline Dependent & & & & & & Lower & Upper \\
\hline Variable & & & & & & Bound & Bound \\
\hline 13. The & Central & Teacher & -.622 & .163 & $.002 *$ & -1.09 & -.15 \\
\hline $\begin{array}{l}\text { intellectual } \\
\text { climate in }\end{array}$ & Office & $\begin{array}{l}\text { Instructional } \\
\text { Coach }\end{array}$ & -.729 & .178 & $.001 * *$ & -1.24 & -.22 \\
\hline the program & & Dean & -.571 & .194 & $.040^{*}$ & -1.13 & -.02 \\
\hline was & & Administrator & -.675 & .254 & .086 & -1.40 & .05 \\
\hline stimulating. & & Other & -.547 & .181 & $.032 *$ & -1.07 & -.03 \\
\hline$\overline{18 .}$ & Instructional & Teacher & .278 & .123 & .215 & -.07 & .63 \\
\hline Textbooks & Coach & Dean & .131 & .190 & .983 & -.41 & .67 \\
\hline required for & & Administrator & -.115 & .293 & .999 & -.95 & .72 \\
\hline $\begin{array}{l}\text { the courses } \\
\text { were used }\end{array}$ & & $\begin{array}{l}\text { Central } \\
\text { Office }\end{array}$ & .274 & .244 & .873 & -.43 & .97 \\
\hline $\begin{array}{l}\text { on a regular } \\
\text { basis. }\end{array}$ & & Other & -.513 & .164 & $.023^{*}$ & .04 & .98 \\
\hline
\end{tabular}

Note: $* p<.05,{ }^{* *} p<.01$ 